Article

\title{
The Effect of Petrographic Characteristics and Physico-Mechanical Properties of Aggregates on the Quality of Concrete
}

\author{
Petros Petrounias ${ }^{1, *}$, , Panagiota P. Giannakopoulou ${ }^{1}$, Aikaterini Rogkala ${ }^{1}$, \\ Panagiotis M. Stamatis ${ }^{1}$ (D), Paraskevi Lampropoulou ${ }^{1}$, Basilios Tsikouras ${ }^{2}(\mathbb{D})$ and \\ Konstantin Hatzipanagiotou ${ }^{1}$ \\ 1 Section of Earth Materials, Department of Geology, University of Patras, 26504 Patras, Greece; \\ peny_giannakopoulou@windowslive.com (P.P.G.); krogkala@upatras.gr (A.R.); \\ panayiotisstamatis@gmail.com (P.M.S.); p.lampropoulou@upatras.gr (P.L.); \\ k.hatzipanagiotou@upatras.gr (K.H.) \\ 2 Physical and Geological Sciences, Faculty of Science, Universiti Brunei Darussalam, Jalan Tungku Link, \\ Gadong BE1410, Brunei Darussalam; basilios.tsikouras@ubd.edu.bn \\ * Correspondence: Geo.plan@outlook.com
}

Received: 5 October 2018; Accepted: 6 December 2018; Published: 8 December 2018

\begin{abstract}
This paper examines the effect of the aggregate type on concrete strength, and more specifically, how the petrographic characteristics of various aggregate rocks as well as their physicomechanical properties influences the durability of C 25/30 strength class concrete. The studied aggregate rocks were derived from Veria-Naousa and Edessa ophiolitic complexes as well as granodiorite and albitite rocks from their surrounding areas in central Macedonia (Greece). Concretes were produced with constant volume proportions, workability, mixing and curing conditions using different sizes of each aggregate type. Aggregates were mixed both in dry and water saturated states in concretes. Six different types of aggregates were examined and classified in three district groups according to their physicomechanical properties, petrographic characteristics and surface texture. The classification in groups after the concrete compressive strength test verified the initial classification in the same three groups. Group I (ultramafic rocks) presented the lowest concrete strengths, depending on their high alteration degree and the low mechanical properties of ultramafic aggregates. Group II (mafic rocks and granodiorite) presented a wide range of concrete strengths, depending on different petrographic characteristics and mechanical properties. Group III (albite rocks) presented the highest concrete strengths, depending on their lowest alteration degree and their highest mechanical properties. Therefore, mineralogy and microstructure of the coarse aggregates affected the final strength of the concrete specimens.
\end{abstract}

Keywords: petrographic characteristics; engineering properties; construction aggregates; concrete petrography

\section{Introduction}

Concrete, a mixture of cement, aggregates and water, is the most used man-made material, [1-4]. The basic component of concrete is the material that binds the aggregate particles together, commonly comprising a mixture of cement and water $[1,5,6]$. Concrete structures can be described as a three-phase system composed by hardened cement paste, aggregate and the interface between aggregate particles and cement paste $[7,8]$. Aggregates are the major constituents of concrete, typically occupying between $70 \%$ and $80 \%$ of its volume. Therefore, it is expected that aggregates have an important influence on the concrete parameters [9]. The selection of the coarse aggregate type in concrete is a dominant 
factor for the quality of concrete. For the same quality cement, different lithotypes of coarse aggregates characterized by different micro-roughness, mineralogical composition, structure and compressive strength may result in different concrete compressive strength [10,11].

Mineralogical composition of the aggregates, and more specifically their alteration degree, strongly influence their mechanical behavior and their in-service performance [10,12-17]. Increased percentages of certain secondary minerals negatively affect the physical, as well as the mechanical properties of aggregates due to their smooth layers, cleavage and platy or fibrous crystal habit $[10,17]$, which have an adverse effect on their performance as concrete aggregates [10]. The increased number of construction failures has highlighted the importance of understanding that mineralogy is a mean to diagnose problems in engineering constructions. The physico-mechanical properties of rocks used as aggregates are the most significant parameters in any application and in their classification for various engineering purposes. Physicomechanical properties depend on the petrographic characteristics (mineralogical composition, texture, size, shape and arrangement of mineral grains, nature of grains contact and degree of grain interlocking), alteration and deformation degree of the source rock [18-22].

Nowadays, many researchers [11,23-25] have endeavored to examine the effect of different lithotypes of aggregates but there are limited results about correlations between different types of aggregates on concrete strength. Ozturan and Cecen [26] have been focused on the influence of coarse aggregate type on mechanical properties of concretes made with basalt and gravel, which have given similar compressive strength, while limestone concrete attained a somewhat higher strength. Yilmaz and Tugrul [11] studied the effect of coarse aggregate on the compressive strength of concrete. They reported that concrete mixtures prepared with subarkose aggregates have nearly $40-50 \%$ higher compressive strength compared to subarkose-arkose, sublitharenite-litharenite and arkose aggregates. Presumably, the combination of mineralogical composition and microroughness of the aggregate particles plays a very important role in the adherence of the cement paste [10]. The high microroughness of the aggregate particles, which is related to the presence of less secondary phyllosilicate minerals and to the differential hardness of their minerals, promotes bonding of the aggregates with the cement paste thus leading to higher quality concretes.

The aim of this study is to investigate the properties of a series of coarse crushed aggregate rocks ranging in composition from acidic through mafic to ultramafic, which can be used for the preparation of concretes. The results of the current investigation show the influence of the mineralogical composition and physico-mechanical properties of different lithotypes on the concrete strength. Moreover, the interfaces between six types of aggregates with the cement paste were investigated, in order to highlight the influence of the mineralogical composition of aggregates on the bond strength of the interface.

\section{Geological Setting}

In this case study, representative ultramafic and mafic rocks from ophiolite complexes, as well as granodiorite and an albitite from Veria-Naousa and Edessa in central Macedonia of Greece were collected and their performances as concrete aggregates were investigated.

\subsection{Veria-Naousa Ophiolitic Complex}

The Veria-Naousa ophiolite complex in northern Greece belongs to the Almopias subzone of the Axios geotectonic zone (Figure 1). This complex consists, from base to top, from serpentinized lherzolite and harzburgite, interfered by few pyroxenitic dykes [27], as well as gabbro, diabase and pillow basalt which are considered to be remnants of oceanic lithosphere that have been placed onto Late Triassic-Jurassic platform carbonates of the Pelagonian Zone, during Upper Jurassic to Lower Cretaceous [28,29]. The serpentinized peridotites are characterized by high tectonic stress, expressed by an intense network of joints. Rare rodingite dykes disrupted these ultramafic rocks. Moreover, conglomeratic limestone, flysch formation and breccia limestone of Neogene to Quaternary age lie uncomfortably on the ophiolitic rocks. Granite to granodiorite intrusion is observed near Trilofos village. 
The eastern contact of the ophiolite with the Pelagonian carbonates is dominated by a cataclastic zone of diabasic fragments and albitite veins. Small-sized bodies of pyroxenites occur within serpentinized harzburgite. Pliocene volcanic rocks of the Almopias subzone ranging in composition from trachyte to andesite occur to the east of the ophiolitic complex.

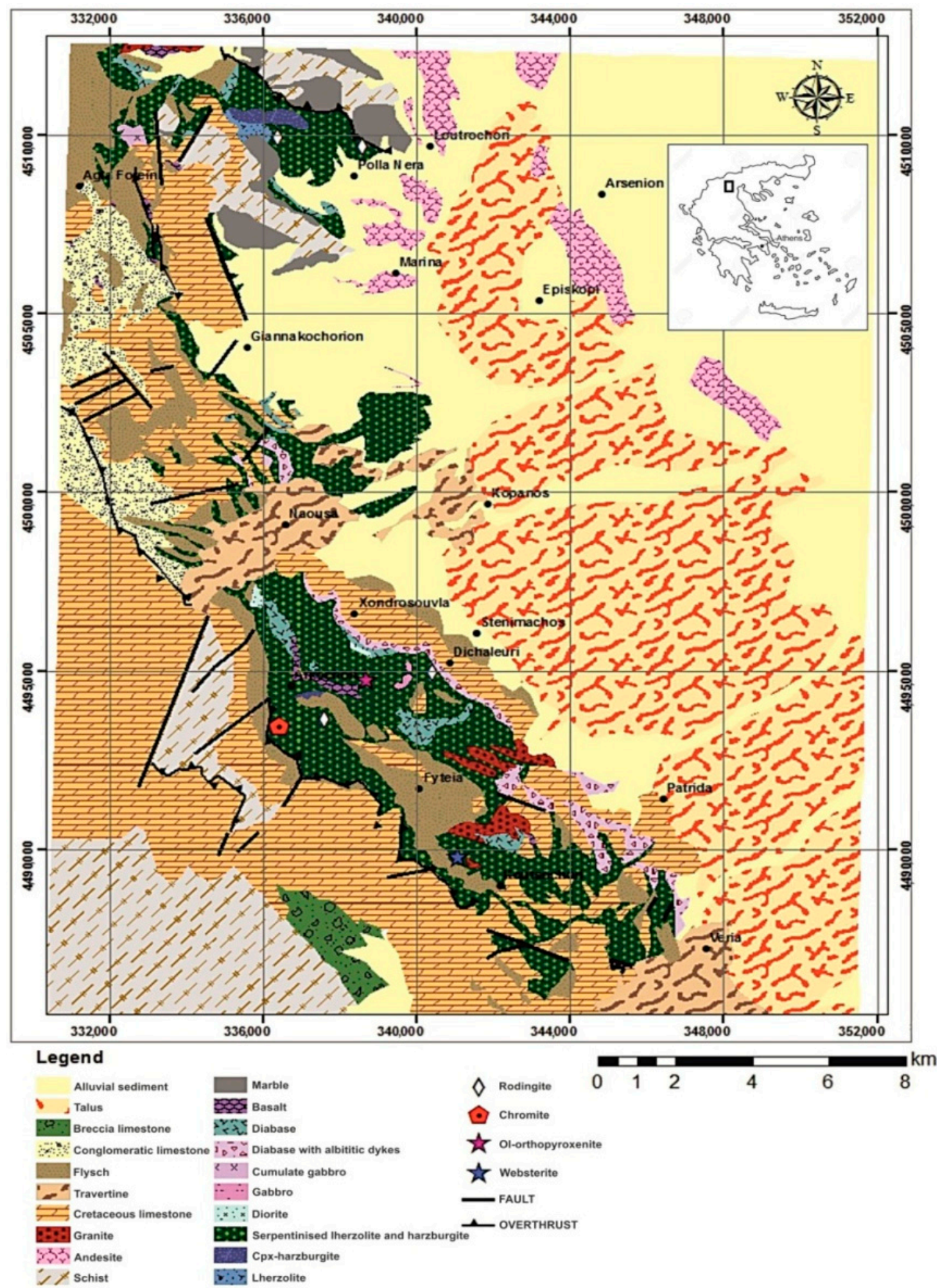

Figure 1. Geological map of the Veria-Naousa region ([10,30]; modified after fieldwork and mapping by using ArcMap 10.1); the rectangle in the inset shows the study area. 


\subsection{Edessa Ophiolitic Complex}

The Edessa ophiolite represents remnants of oceanic lithosphere, which was thrust out of one or more ocean basins during Upper Jurassic to Lower Cretaceous time [31,32]. It is tectonically very complex and consists of several tectonic units $[29,33]$. The ophiolitic complex includes highly serpentinized lherzolite, serpentinized harzburgite diorite, gabbro, diabase and basalt (Figure 2). The serpentinized harzburgite is the dominant rock type among the ultramafic rocks and enclose chromitite, which forms lenses or beds. Massive diabase and basalt are thrust over serpentinized harzburgite and pass upwards into basaltic pillow-lava flows. The ophiolitic complex is dismembered and scattered due to the intensive tectonism. Ophiolitic rocks are conformably overlain by Middle-Upper Cretaceous to Paleocene transgressive sediments (conglomeritic limestone) and Neocene deposits (alluvial sediments, talus, travertine) as well as flysch formation (Figure 2). Furthermore, volcanic rocks are east of the ophiolites and they belong to the Almopias subzone. They are andesites and rhyolite which formed during Pliocenic time, and according to Sr-Nd isotopes, they associated with a SSZ tectonic environment [34].

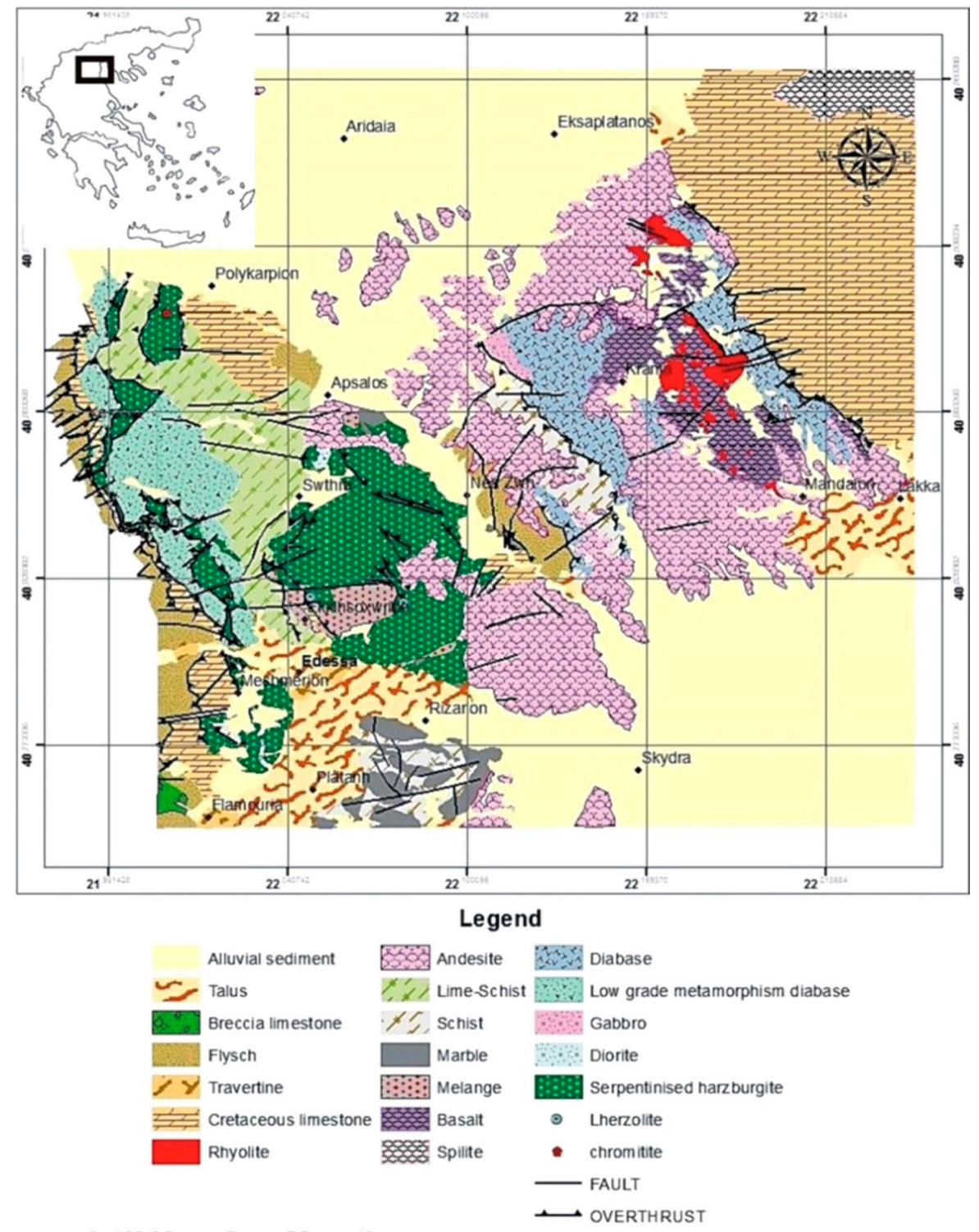

Figure 2. Geological map of the Edessa region ([35]; modified after fieldwork and mapping by using ArcMap 10.1); the rectangle in the inset shows the study area. 


\section{Materials and Methods}

\subsection{Materials}

Twelve samples from crushed aggregates from six different lithologies were used to prepare concrete specimens (Table 1). The same aggregates were tested for their physicomechanical properties (Table 2). Normal Portland cement (CEM II 32.5N), which conformed to EN 197-1 [36] was used with the aggregates for the production of concrete. Potable tap water, free of impurities such as salt, silt, clay and organic matter, was used for mixing and curing the concrete. The $\mathrm{pH}$ value of water was 7.0. In order to keep a consistent composition for all the concrete specimens, we adopted the principle of maintaining the same volume of aggregate per $1 \mathrm{~m}^{3}$ of the mixture. The proportions of the concrete mixtures, by mass, were 1/6/0.63 cement, aggregate and water ratio.

\subsection{Aggregate Tests}

The studied samples were first crushed into smaller pieces by hammer. Aggregate fractions were prepared from the smaller pieces using a laboratory jaw crusher. Laboratory core drill and saw machines were used to prepare cylindrical specimens. Their diameters range between 50 and $54 \mathrm{~mm}$ and the ratio of length to diameter was between 2.2 and $2.5 \mathrm{~mm}$.

The physical properties that were studied for the tested samples were the total porosity $\left(\mathrm{n}_{\mathrm{t}}\right)$ and the moisture content $(\mathrm{w})$. In the studied samples the moisture content $(\mathrm{w})$ was measured according to the standard AASHTO T-255 [37]. The total porosity $\left(\mathrm{n}_{\mathrm{t}}\right)$ was calculated using specimens of rocks according to the ISRM 1981 standard [38].

The examined mechanical properties of the rock samples were the Los Angeles abrasion value (LA) and the uniaxial compressive strength (UCS). The Los Angeles abrasion (LA) is a test to determine coarse aggregate strength. It is the test of resistance to fragmentation in accordance with ASTM C-131 [39]. The uniaxial compressive strength (UCS) was examined on core cylindrical samples according to the ASTM D 2938-95 [40] specification and the arithmetic mean value was calculated for six specimens of each sample.

The mineralogical and textural characteristics were examined in polished thin sections with a polarizing microscope according to EN-932-3 [41] standard for petrographic description of aggregates. Thin sections were prepared to study the mineralogical composition and textural characteristics of the studied rocks. The thin sections were examined under a petrographic microscope (Leitz Ortholux II POL-BK Ltd., Midland, ON, Canada) for mean grain size and grain shape. The bulk mineral composition of the studied samples was also determined by X-ray Diffraction (XRD), using a Bruker D8 advance diffractometer, with Ni-filtered $\mathrm{CuK}_{\alpha}$ radiation. Random powder mounts were prepared by gently pressing the powder into the cavity holder. The scanning area for bulk mineralogy of specimens covered the $2 \theta$ interval $2-70^{\circ}$, with a scanning angle step size of $0.015^{\circ}$ and a time step of $0.1 \mathrm{~s}$. The mineral phases were determined using the DIFFRACplus EVA $12^{\circledR}$ software (Bruker-AXS, Gmbtl, Karlsruhe, Germany) based on the ICDD Powder Diffraction File of PDF-2 2006.

The surface texture of aggregate samples was studied by using Secondary Electron Images (SEI) according to BS 812 Part 1 [42], which outlines six qualitative categories, i.e., glassy, smooth, granular, rough, crystalline, honeycomb and porous.

\subsection{Concrete Tests}

Twelve normal concrete cube specimens $(150 \times 150 \mathrm{~mm})$ were made from the six different aggregate types (Table 1), according to ACI-211.1-91 [43]. All of the parameters remained constant in all the concrete specimens. The aggregate were crushed through standard sieves a separated into the size classes of 2.00-4.75, 4.45-9.5 and 9.5-19.1 mm. After $24 \mathrm{~h}$, the samples were removed from the mold and were cured in water for 28 days. Curing temperature was $20 \pm 3{ }^{\circ} \mathrm{C}$. These specimens were tested in a compression testing machine at an increasing rate of load of $140 \mathrm{~kg} / \mathrm{cm}^{2}$ per minute. The compressive strength of concrete is calculated by the division of the value of the load at the 
moment of failure over the area of specimen. The compression test was elaborated according to BS EN 12390-3:2009 [44].

After the compressive strength test, the textural characteristics of concretes were examined. Polished thin sections were studied in a polarizing microscope according to ASTM C856-17 [45].

Table 1. Number of concrete cubes for each aggregate type.

\begin{tabular}{ccccccc}
\hline Aggregate Type & Diabase & Serpentinite & Albitite & Gabbro & Diorite & Granodiorite \\
\hline Concrete cube & 4 & 2 & 2 & 2 & 1 & 1 \\
\hline
\end{tabular}

\section{Results}

\subsection{Physico-Mechanical Properties of Aggregates}

The results of the physicomechanical properties enabled us to determine three discrete groups (Table 2). Mechanical and physical values of the tested rocks display a wide variation even within the same lithology.

Table 2. Results of physical and mechanical properties of the studied aggregates.

\begin{tabular}{|c|c|c|c|c|c|c|}
\hline $\begin{array}{l}\text { Samples } \\
\text { Grading }\end{array}$ & Aggregate & Lithotype & $\begin{array}{l}\text { Porosity } \\
\text { (\%) }\end{array}$ & $\begin{array}{c}\text { Moisture } \\
\text { Content (\%) }\end{array}$ & $\begin{array}{c}\text { Los Angeles } \\
(\%)\end{array}$ & $\begin{array}{c}\text { Compressive } \\
\text { Strength }(\mathrm{MPa}) \\
(\mathrm{N}=6)\end{array}$ \\
\hline \multirow{2}{*}{ Group I } & BE.122B & Serpentinite & 3.21 & 1.25 & 25.51 & 34.00 \\
\hline & BE.103C & Serpentinite & 4.99 & 1.94 & 28.97 & 39.00 \\
\hline \multirow{8}{*}{ Group II } & ED.24 & Diabase & 0.84 & 0.52 & 14.15 & 91.33 \\
\hline & BE.113 & Diabase & 0.45 & 0.42 & 7.39 & 97.15 \\
\hline & ED.94 & Diorite & 2.27 & 0.64 & 18.40 & 85.00 \\
\hline & ED.66A & Diabase & 0.38 & 0.46 & 7.65 & 73.00 \\
\hline & BE.100 & Gabbro & 0.88 & 0.47 & 13.88 & 65.00 \\
\hline & BE.149 & Diabase & 0.97 & 0.35 & 10.25 & 70.00 \\
\hline & ED.26 & Gabbro & 1.74 & 0.60 & 20.68 & 65.00 \\
\hline & BE.139 & Granodiorite & 1.70 & 0.60 & 7.71 & 91.00 \\
\hline \multirow{2}{*}{ Group III } & BE.108 & Albitite & 0.31 & 0.29 & 13.05 & 140.00 \\
\hline & BE.150 & Albitite & 0.29 & 0.27 & 11.00 & 145.00 \\
\hline
\end{tabular}

* Compressive strength (MPa) in cylindrical core samples.

Three groups of aggregate rocks were determined in terms of their physico-mechanical properties (Table 2). Group I included ultramafic aggregates, which displayed the worst values of mechanical properties among all groups (Table 2). Among the studied aggregates of Group I, sample BE.103C, which contained a higher amount of serpentine, gave a higher value of total porosity $\left(n_{t}\right)$ and lower resistance in abrasion and attrition than the sample BE.122B, which was characterized by less extended serpentinization. Group II was composed of mafic rocks and granodiorite (Table 2) and showed a wide variance of their physico-mechanical properties due to the variability of their mineralogical features and as well as their tectonic stress. The fine-grained diabases, such as BE.113 and ED.66A, presented better mechanical characteristics against to the coarse-grained gabbros (BE.100 and ED.26) even if they present similar degree of alteration, as describing below in Section 4.2 (Petrographic features of aggregates).

Group III included intermediate rocks, which displayed high physicomechanical parameters among all the determined groups. The low total porosity of these aggregates classified them as the best group of studied rocks. 


\subsection{Petrographic Features of Aggregates}

The groups described were based on the classification that occurred due to the physico-mechanical properties of the studied rock samples. Group I was comprised of highly serpentinized ultramafic rocks. The primary assemblage of the serpentinites constituted less than $30 \%$ of the mode and comprised relics of orthopyroxene, rare clinopyroxene, olivine, as well as spinel. Orthopyroxene appeared as subhedral porphyroclasts and most of them showed exsolution lamellae of clinopyroxene. Serpentine was the main alteration product (Table 3) showing mesh and ribbon textures (Figure 3a). The areas occupied by serpentine usually display pseudomorphic, mesh and ribbon textures. Chlorite and magnetite are also products of hydrothermal alteration. The deformation of these samples (Table 2) is primarily brittle, as expressed by the numerous intragranular and transgranular microcracks.

Table 3. Petrographic characteristics of the studied aggregate rocks.

\begin{tabular}{|c|c|c|c|c|}
\hline Samples Grading & Samples & Lithotype & Primary Minerals & $\begin{array}{l}\text { Secondary } \\
\text { Minerals }\end{array}$ \\
\hline \multirow{2}{*}{ Group I } & BE.103C & Srp. Lherzolite & opx, ol, cpx, sp & srp, mgt, bas \\
\hline & BE.122B & Srp. Harzburgite & opx, ol, sp & srp, mgt, bas \\
\hline \multirow{8}{*}{ Group II } & ED.94 & Diorite & $\mathrm{plg}, \mathrm{hbl}, \mathrm{cpx}, \mathrm{or}, \mathrm{qz}, \mathrm{ttn}$ & ser, act, chl, stl \\
\hline & BE.100 & Gabbro & $\mathrm{cpx}, \mathrm{plg}, \mathrm{ttn}$ & chl, act, ep \\
\hline & ED.26 & Gabbro & cpx, plg, ttn & chl, ser, ep, phr \\
\hline & ED.24 & Diabase & plg, cpx & act, chl, ep, phr, ser \\
\hline & BE.113 & Diabase & plg, cpx & chl, act, ep \\
\hline & ED.66A & Diabase & plg, cpx & chl, ep, ser, act \\
\hline & BE.139 & Granodiorite & $\mathrm{qz}, \mathrm{plg}$, or & chl, ep, ser, stl \\
\hline & BE.149 & Granodiorite & $\mathrm{qz}, \mathrm{plg}$, or & chl, ep, ser \\
\hline \multirow{2}{*}{ Group III } & BE.108 & Albitite & plg, cpx, qz & chl, ep, ser \\
\hline & BE.150 & Albitite & plg, cpx, qz & chl, ep, ser \\
\hline
\end{tabular}

(ol = olivine, $\mathrm{opx}=$ orthopyroxene, $\mathrm{cpx}=$ clinopyroxene, $\mathrm{sp}=$ spinel, act $=$ actinolite, bas $=$ bastite, $\mathrm{chl}=\mathrm{chlorite}$, $\mathrm{mgt}=$ magnetite, $\mathrm{tr}=$ tremolite, $\mathrm{ep}=$ epidote, $\mathrm{plg}=$ plagioclase, $\mathrm{qz}=$ quartz, $\mathrm{hbl}=$ hornblende, $\mathrm{stl}=$ stilpnomelane, $\mathrm{ttn}=$ titanite, $\mathrm{ser}=$ sericite, $\mathrm{phr}=$ prehnite).

Group II was comprised of gabbro, diabase, diorite and granodiorite. The gabbro consisted mainly of clinopyroxene and plagioclase. Ilmenite, magnetite, titanite and zircon were accessory phases (Figure 3b). Actinolite, epidote, chlorite and calcite were products of ocean-floor metamorphism. The diabase samples exhibited porphyritic, ophitic and subophitic textures. The mineral assemblage was similar to that of gabbros, including clinopyroxene and subhedral plagioclase (Figure 3c). In some cases, the plagioclase was partially to completely transformed to sericite (Table 3). Accessory ilmenite, magnetite and titanite occurred as well. Actinolite, epidote, prehnite and chlorite were secondary phases. A great number of transgranular microcracks were observed in some diabases (ED.66A and BE.149). The diorite was moderately altered, fine to medium-grained samples. Its texture was granular but became locally porphyritic with subhedral to euhedral plagioclase phenocrysts. Sporadic, euhedral hornblende grains were poikilitically enclosed within larger plagioclase crystals. Primary assemblage includes clinopyroxene, plagioclase and hornblende. Minor magnetite and ilmenite were also present. Ocean-floor metamorphism resulted in the development of chlorite, actinolite, sericite, albite, epidote and stilpnomelane. Additionally, quartz fills transgranular microcracks crosscutting the rock. Granodiorite was characterized by poikilitic textures and was composed of plagioclase, quartz, orthoclase, biotite and accessory phases including apatite, titanite and zircon. Secondary minerals were epidote, actinolite and chlorite (Figure 3e).

Group III was comprised of albitite rocks (Table 2). Albitite is a leucocratic and fine grained rock (Figure 3f). They presented mainly granular texture where idiomorphic albite, quartz and clinopyroxene were the primary minerals, while chlorite and epidote were the secondary phases (Table 3). Accessories included apatite, zircon and Fe-oxides. 

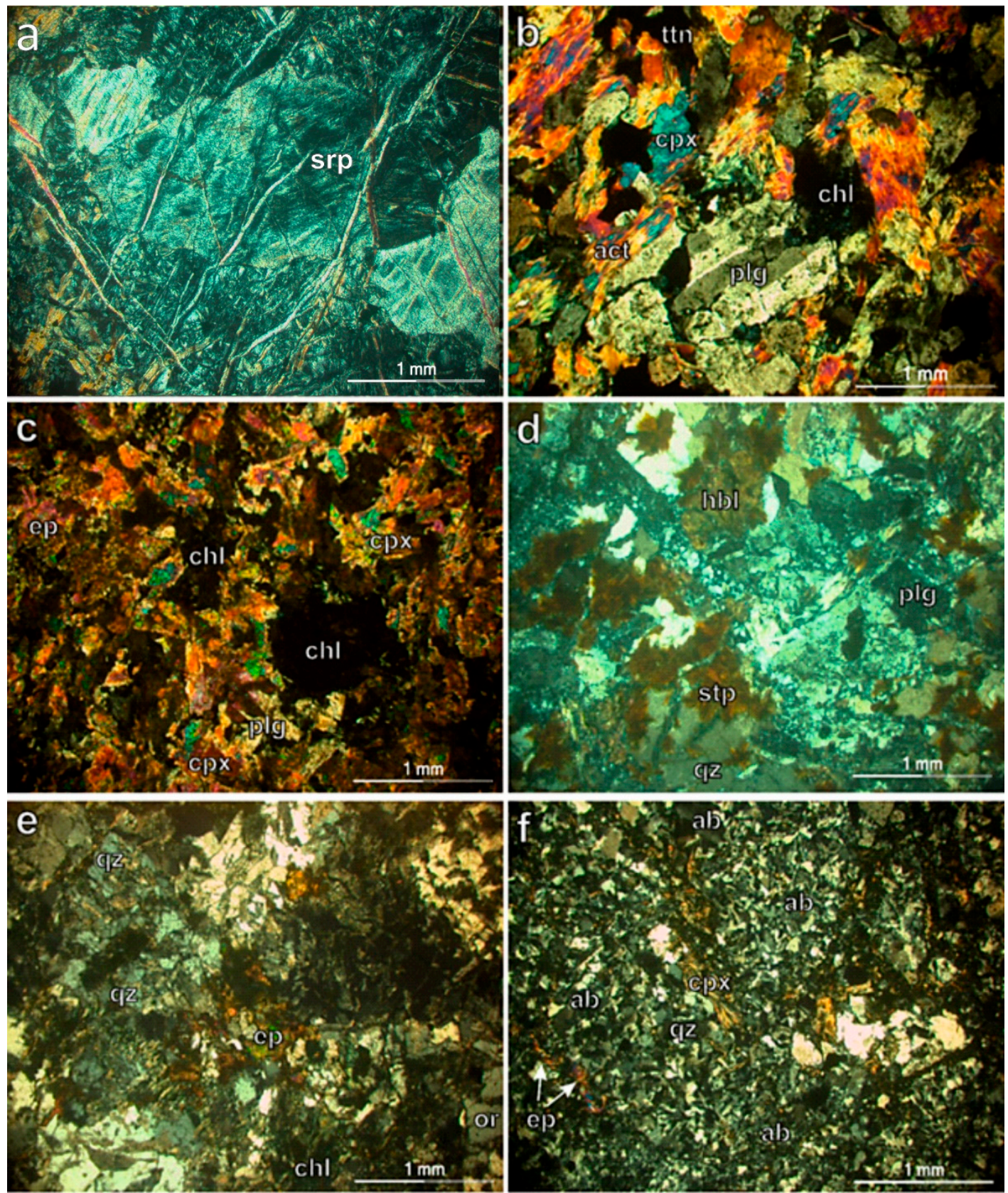

Figure 3. Photomicrograph of textural characteristics of aggregates (Nicols+): (a) mesh texture presented in a serpentinite (sample BE.103C); (b) irregular plagioclase (plg) and clinopyroxene (cpx) forming ophitic texture accompanied by subhedral grains of titanite (ttn) and actinolite (act), in a gabbro (sample BE.100); (c) subophitic texture with plagioclase (plg) and clinopyroxene (cpx) altered to epidote (ep) and chlorite (chl) (sample ED.24); (d) plagioclase (plg), hornblende (hbl), stilpnomelane (stp) and quartz (qz) forming granular texture in a diorite (sample ED.94); (e) granodiorite with poikilitic texture where crystals of quartz (qz), orthoclase (or), epidote (ep) and chlorite (chl) are present (sample BE.139) (f) fine grained idiomorphic albite (ab) with quartz (qz), clinopyroxene (cpx) and epidote (ep) in an albitite (sample BE.108).

\subsection{XRD Analysis of Aggregates}

Besides the microscopic observation of the studied rock samples through polarizing microscope, their mineralogical composition was also identified with the aid of the X-ray diffraction in accordance with the EN 932-9 [41] standard for the petrographic description of aggregate rocks. The X-ray 
diffraction enabled us to identify the crystalline phases of the studied rocks. Representative XRD patterns of the samples are shown below (Figure 4).
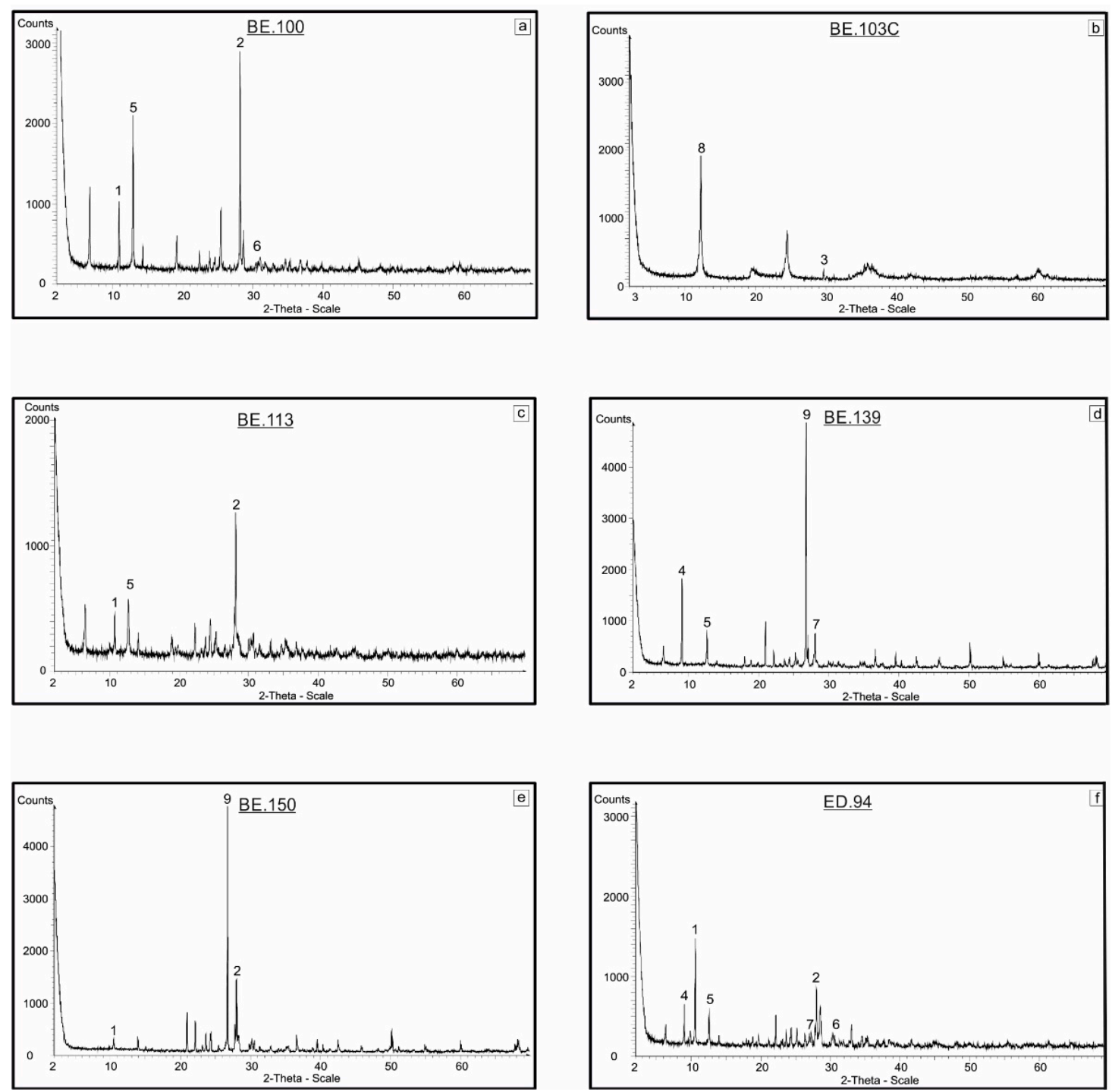

Figure 4. X-ray diffraction patterns of representative aggregate rocks: (a) gabbro (sample: BE.100), (b) serpentinite (sample: BE.103c), (c) diabase (sample: BE.113), (d) granodiorite (sample: BE.139), (e) albitite (sample: BE.150), (f) diorite (sample: ED.94), (1: actinolite, 2: albite, 3: augite, 4: biotite, 5: chlorite, 6: epidote, 7: K-feldspar, 8: lizardite, 9: quartz).

The XRD patterns of random powder mounts from the studied ultramafic rocks revealed that serpentine is the main alteration product in all samples of Group I.

In Group II, the XRD patterns of the samples revealed the presence of clinopyroxene, plagioclase, chlorite and actinolite. Quartz, titanite and epidote were also present, while titanite and ilmenite were present in the gabbro.

In Group III, the XRD patterns of the samples revealed the presence of quartz and plagioclase.

\subsection{Surface Texture of Aggregates}

The microroughness of the aggregate particles was used to categorize the aggregates in groups consistent with the abovementioned Groups I to III. Particles of Group I show smooth surfaces, due to the abundance of the sheet-like serpentine (Figure $5 a, b)$. Samples of Group II were medium-grained rocks and were characterized by a rough surface texture (Figure $5 c, d$ ). Juxtaposed clinopyroxene, 
actinolite and plagioclase with chlorite created high topographic features. Crystalline surface with topographic highs of quartz and low areas with albitite (Figure 5e,f) were observed in Group III.
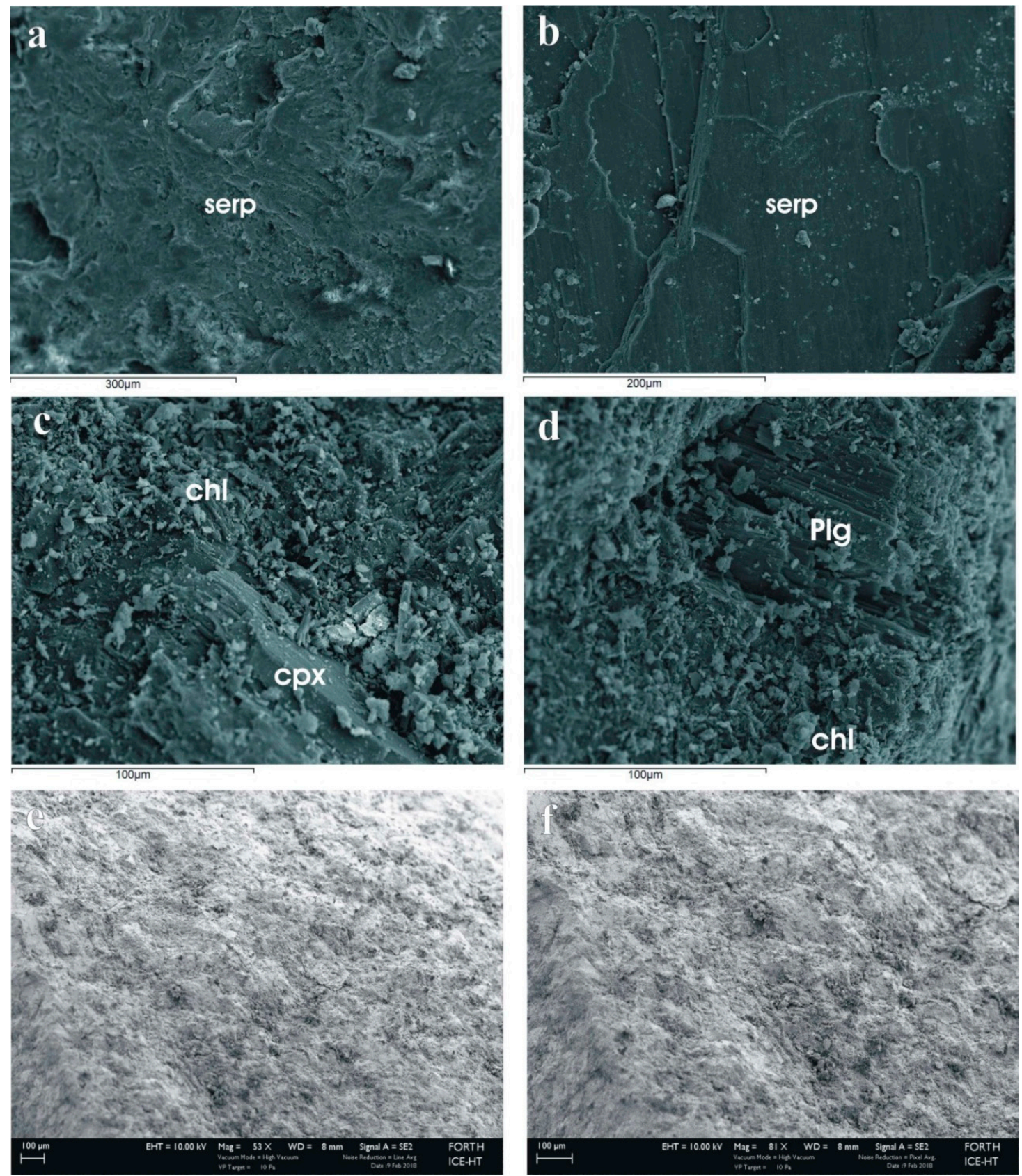

Figure 5. Secondary electron images (SEI) images showing the surface texture of representative ultramafic, mafic and intermediate samples observed to their mineralogical and textural features: (a) serpentinite (BE.103C), (b) serpentinite (BE.122B), (c) gabbro (ED.26), (d) diabase (BE.113), (e) albitite (BE.108), (f) albitite (BE.150).

\subsection{Test Results for Concrete}

\subsubsection{Compressive Strength of Concrete}

The results from the compressive strength test of concrete specimens are listed in Table 4 . The concrete strength ranged from 28 to $32 \mathrm{MPa}$ after 28 days of curing. The concretes made from aggregates of Groups I to III yielded UCS results, consistent with the strength of their aggregates. 
Hence, the classification in groups after the concrete compressive strength test verified their initial classification in groups. The lowest compressive strength values of the concrete specimens were obtained from the samples made with aggregates from Group I (Table 4). The concrete specimens, made with aggregates from Group II, showed variance on strength values (29 to $32 \mathrm{MPa}$ ), while those made with aggregates from Group III presented the highest compressive strength values.

Table 4. Compressive strength of concrete specimens of different aggregate types.

\begin{tabular}{cccc}
\hline & Aggregate Rock Sample & Lithotype & Compressive Strength (MPa) $^{*}$ \\
\hline \multirow{2}{*}{ Group I } & BE.122B & Serpentinite & 28 \\
& BE.103C & Serpentinite & 28 \\
\hline \multirow{5}{*}{ Group II } & ED. 24 & Diabase & 31 \\
& BE.113 & Diabase & 32 \\
& ED. 94 & Diorite & 29 \\
& ED.66A & Diabase & 31 \\
& BE.100 & Gabbro & 30 \\
& BE.149 & Diabase & 30 \\
\multirow{2}{*}{ Group III } & ED.26 & Gabbro & 29 \\
& BE.139 & Granodiorite & 31 \\
\hline
\end{tabular}

\subsubsection{Petrographic Features of the Concretes}

The degree of cement hydration, micro-cracking and reaction products were determined from petrographic observation of the thin sections of the concrete specimens using polarizing and scanning electron microscopes. Microcracks in the interfaces between the cement paste and the aggregate particles were also observed. Careful microscopic observations revealed that intergranular cracks within the coarse aggregates from Group I propagated into the cement paste (Figure $6 c, d$ ). This fact indicates that flaws and cracks of highly serpentinized aggregate particles were expanded during curing of the concretes, thus triggering defects and weaknesses in it. Group II aggregates showed much better cohesion with the cement paste (Figure 6e,f). However, microcracking in the interfaces between the cement paste and the Group II coarse aggregate particles (de-bonding) were observed (Figure 6a,b). Microscopic observation of the concretes, prepared with Group III aggregates, showed that few microcracks developed only at the interfaces between the cement paste and the aggregate particles. Traces of alkali-silica reaction product were identified filling the cracks inside the Group III coarse aggregate particle cracks as well as inside the cracks crossing the cement paste. A rim of gel was observed in the interface of a coarse particle and the cement paste. This gel of a brownish color was characterized by no specific structure, no crystals or by not very well defined crystals.

Scanning electron microscopy was employed to elaborate the reasons for the variable behavior of the aggregates with the cement paste.

In general, Group I aggregates showed bad cohesion mainly due to the petrographic features of serpentine (i.e., platy abruptions). Moreover, in the total of concretes made by ultramafic aggregates, a reaction zone of few microns thick was detected (Figure $7 \mathrm{a}, \mathrm{b}$ ).

Unlike Group I, Group II aggregates generally presented better cohesion with the cement paste. Nevertheless, in some samples, coarse grained gabbro and diorite aggregates showed loss of material at the interface with the cement paste (Figure $7 \mathrm{c}, \mathrm{d}$ ). On the other hand, concretes made by fine grained mafic rocks, and more specifically diabases, presented better cohesion than the coarse grained mafic rocks.

In general, Group III aggregates presented high cohesion with the cement paste. Local reaction zones were detected around the albitite aggregate particles, as well as into their microcracks (Figure 7e,f). 

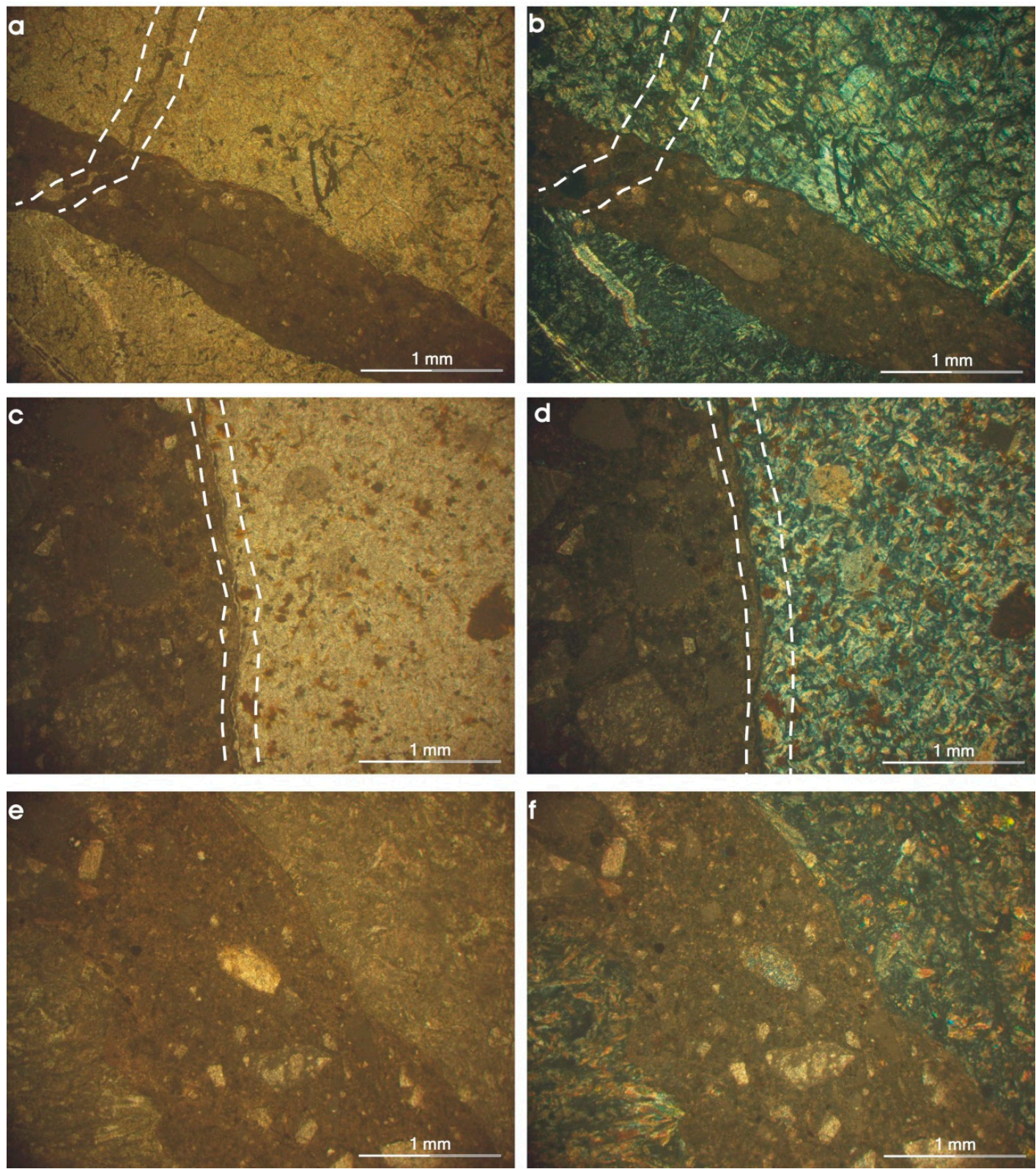

Figure 6. Photomicrographs of representative tested concretes (Parallel nicols (left), Crossed nicols (right)): (a,b) loss of material between the diorite aggregate grains (ED.94) and the cement paste, $(\mathbf{c}, \mathbf{d})$ transgranular microcracks of serpentinite aggregate grains (BE.103C) and cement paste, (e,f) good cohesion between diabase aggregate grains (BE.113) and cement paste.

Semi-quantitative SEM_EDX analyses of these rims, as well as elemental mapping indicated high contents of $\mathrm{Si}, \mathrm{Al}, \mathrm{Na}$ and $\mathrm{K}$, therefore suggesting that these rims comprised alkali-silica gels. Analyses were performed at different locations in order to assess the possible connection between the chemical composition of the zone and the optical features under a polarizing microscope. In order to confirm that it was alkali-silica gel, element mapping was performed in the concrete thin sections, where scarce concentrations of $\mathrm{Si}$ and $\mathrm{Al}$ have been observed in the reaction zone between the aggregate particle and the cement paste, as well as a semi-quantitative composition that was obtained by SEM-EDX. Analyses were performed in different locations in order to assess the possible connection between the chemical composition of the zone and the optical features under a polarizing microscope. Reaction products at the contact interfaces between aggregate particles and the cement paste, which predominantly crystalline, whereas reaction products along particle edges and in paste cracks were mostly amorphous 
(ASR gel) (Figure 8a). The ASR in the concrete specimens may occurs by reaction of certain silica phases in the albitite aggregate with alkali and hydroxide ions in the pore solutions of the hydrating cement to produce a hydrous alkali silicate gel. The analyzed amorphous structure can explain the intrinsic properties of the ASR product, such as its variable $\mathrm{Na} / \mathrm{K}$ ratio, stability in an alkaline environment and cation exchange and swelling capabilities. The exchangeability of water and cations appears very similar to the mechanisms known for clay swelling minerals in the concrete specimens changing lattice parameters and leading to swelling or contraction. This gel was composed mainly by Si and lesser by $\mathrm{K}, \mathrm{Na}$ and $\mathrm{Al}$ (Figure 8b). As shown in Figure 8c-f, variation in chemical composition was presented in the contact of the aggregate particle and the cement paste after line scan investigation, even though the spot microanalyses were affected by surrounded phases (spot area $10 \mu \mathrm{m}$ ). However, the accurate chemical composition of the products of reaction needs further study.
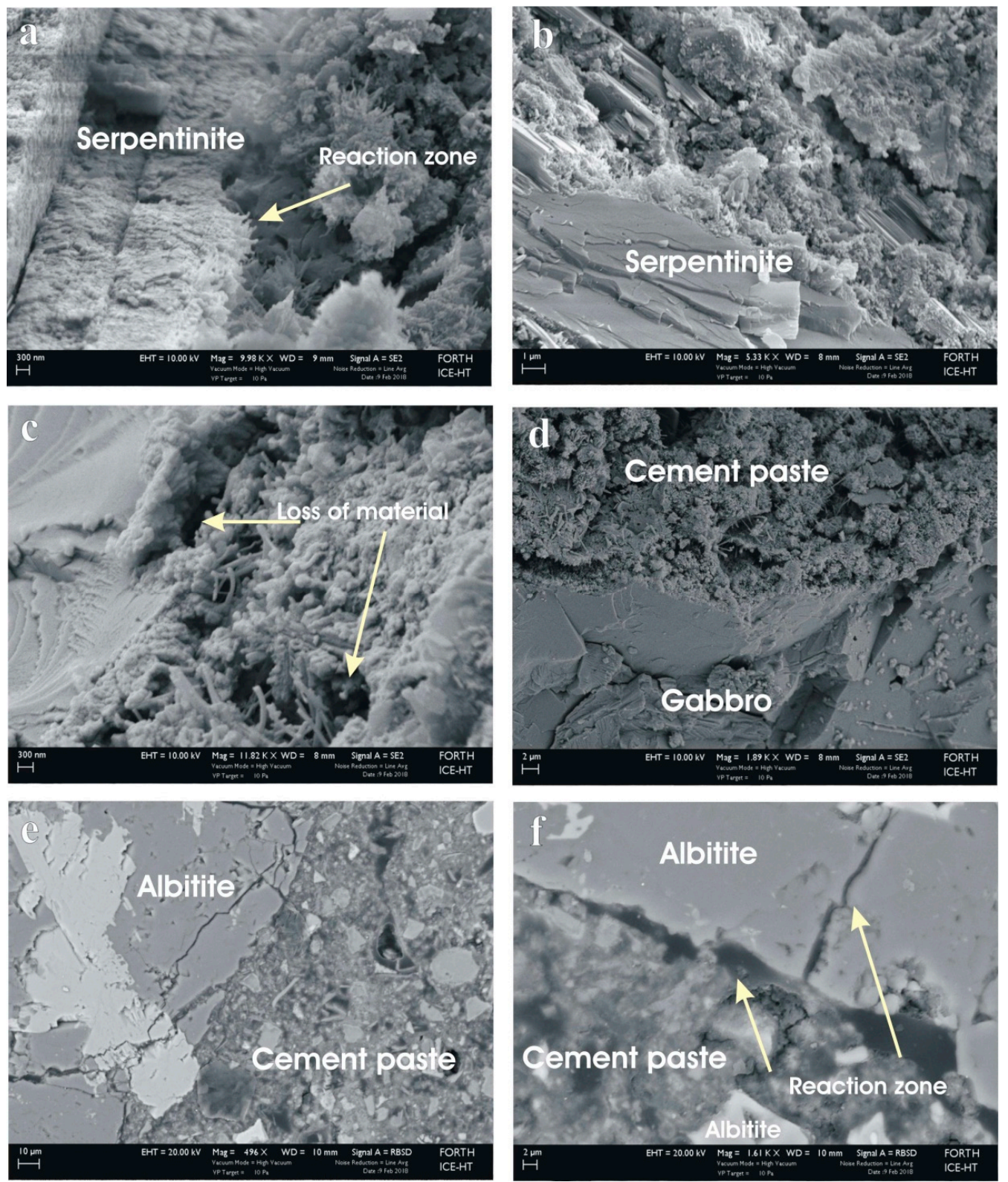

Figure 7. Secondary electron images of the concrete specimens showing microstructures at the interface between cement paste and: (a,b) serpentinite aggregate (BE.103C); (c,d) gabbro aggregates (BE.100, ED.26 respectively); (e,f) back Scattered images showing microstructures at the interface between cement paste and albitite aggregates (BE.108, BE.150). 

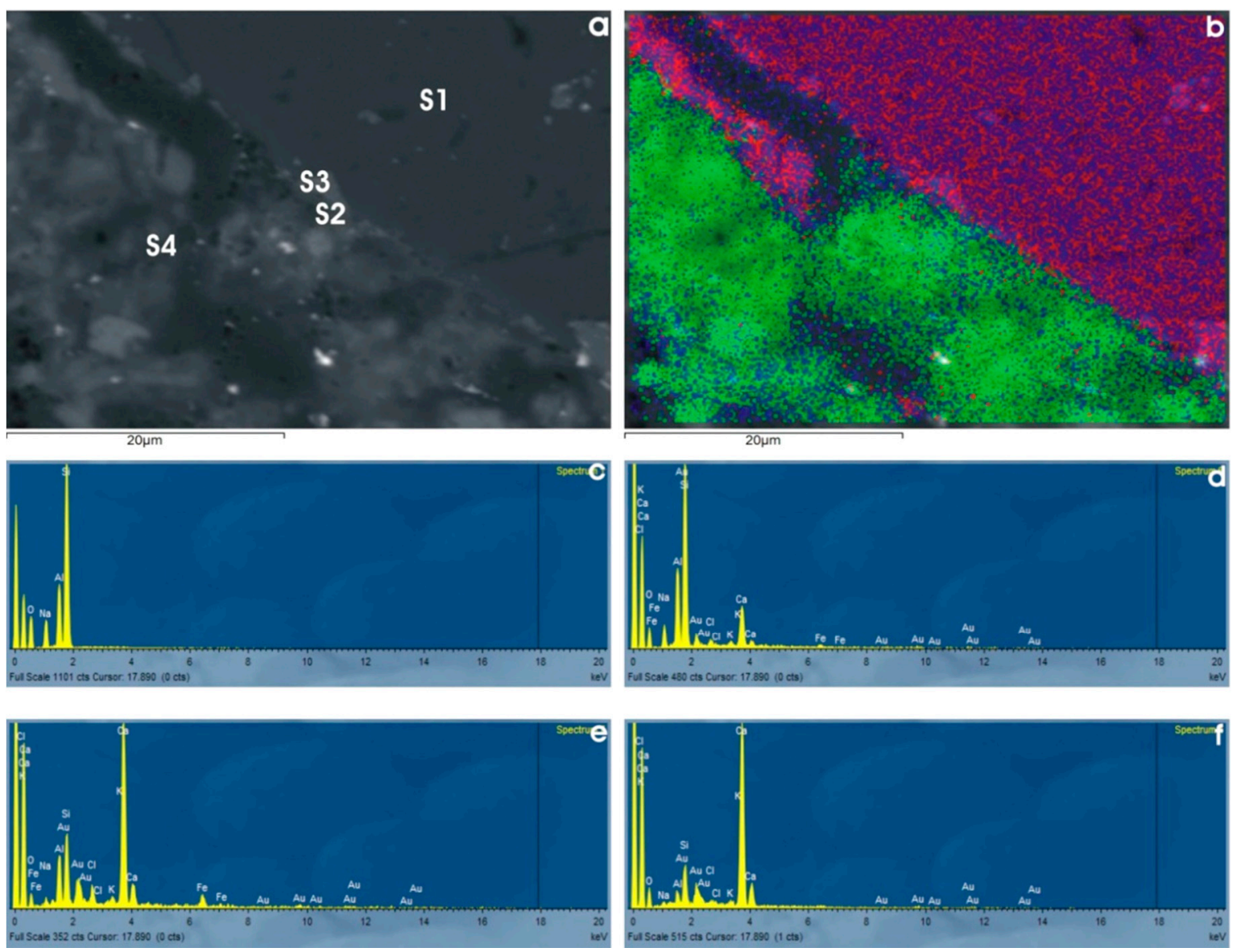

Figure 8. (a) Back scattered image of a concrete specimen showing the ASR zone between the aggregate particle (BE.108) and the cement paste. The SEM-EDX spectra shown in panels (c-f) were acquired from the locations of labeled as S1, S2, S3, S4, respectively. (b) elemental mapping of the interface between an albitite aggregate and the cement paste in a concrete specimen; green color shows Ca concentrations, red color shows Si concentrations and blue color shows Al concentrations. (c-f) SEM-EDX spectra from the interface of an albitite aggregate particle (BE.108) with the cement paste from the spots labeled as S1 to S4 in panel (a).

\section{Discussion}

The physico-mechanical parameters of aggregate materials have been investigated by various researchers for the evaluation of their quality. Mineralogical composition, textural features, alteration degree and weathering of aggregate rocks are the main factors that affect the physico-mechanical properties, and consequently, their suitability for various industrial applications [46] as well as in the final mechanical behavior of constructions.

A number of researchers have studied the relationships between the physical and the mechanical properties of aggregate rocks $[21,47,48]$. The most common statistical method used for the determination of the relationships between the various engineering parameters of rocks is the regression analysis $[20,49,50]$. High correlations are observed between physical and mechanical properties of the studied aggregates, which are related to their mineralogical and petrographic characteristics (Figure 9a,b). Moisture content increases is inversely correlated with uniaxial compressive strength with the exponential equation: $\mathrm{UCS}_{(\mathrm{agg})}=122.41 \mathrm{e}^{-0.723 \mathrm{w}(\mathrm{agg})},\left(R^{2}=0.64\right)$. Total porosity of the aggregates is directly correlated with their resistance in abrasion and attrition with the linear equation: $\mathrm{LA}_{(\mathrm{agg})}=4.356 \mathrm{n}_{\mathrm{t}(\mathrm{agg})}+8.3418,\left(R^{2}=0.75\right)$. 
a

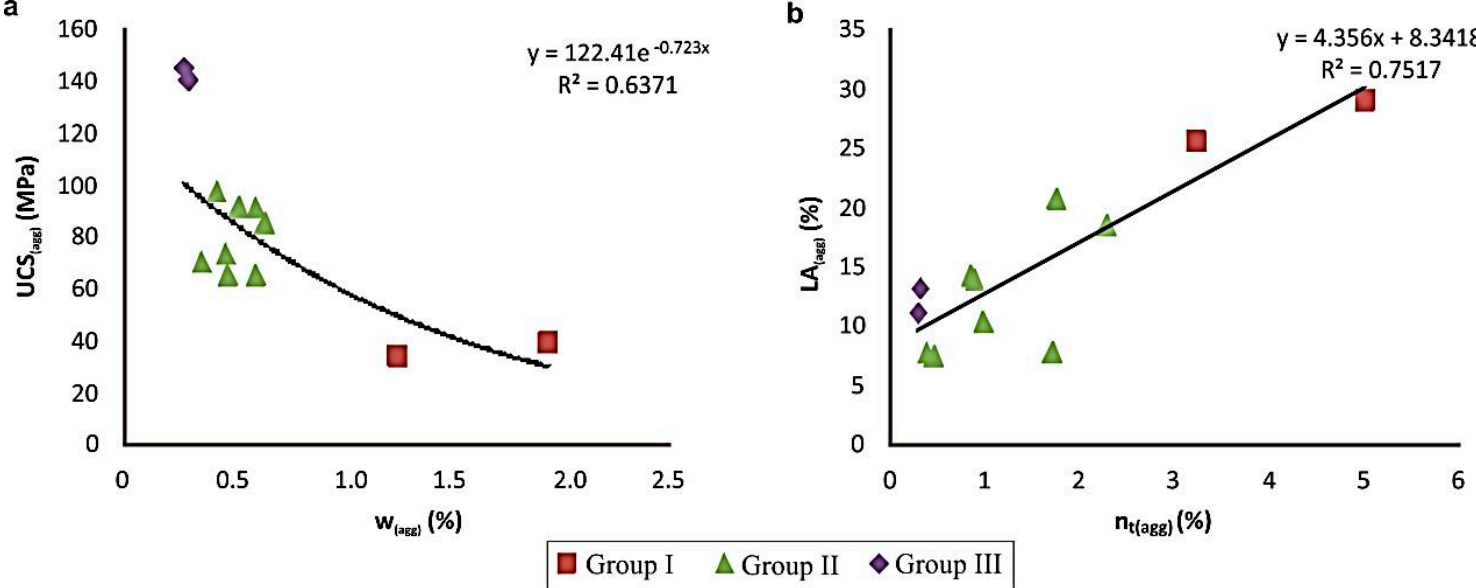

Figure 9. (a) The moisture content $\left(\mathrm{w}_{(\mathrm{agg})}\right)$ of the studied rock samples plotted against the uniaxial compressive strength $\left(\mathrm{UCS}_{(\mathrm{agg})}\right)$; $(\mathbf{b})$ the total porosity $\left(\mathrm{n}_{\mathrm{t}(\mathrm{agg})}\right)$ of the studied rock samples plotted against the Los Angeles abrasion value $\left(\mathrm{LA}_{(\mathrm{agg})}\right)$.

Three groups of aggregate rocks were determined in terms of their physico-mechanical properties (Figure 9). These three groups consisted of aggregate rocks with different mineralogical and petrographic characteristics, which have a direct impact on their physico-mechanical properties. Group I included highly serpentinized and distorted ultramafic rocks (Table 2). This group was characterized by high values of porosity, low values of uniaxial compressive strength and low resistance in abrasion and attrition because of their high degree of serpentinization. High porosity and Los Angeles abrasion (LA) and low uniaxial compressive strength (USC) values of Group I aggregates was attributed to serpentinization, which is an important geochemical process accompanying the formation of the ocean floor [51]. In this process, olivine and pyroxene transform to serpentine, a laminate soft mineral that belongs to the phyllosilicate subclass of minerals and forms smooth surfaces $[10,51,52]$. The influence of serpentine on the aggregate strength as well as on the final compressive strength of concrete specimens has been investigated by several researchers [10,17,46,53,54].

Similar to Group I, the decreasing of the mechanical strength of aggregate rocks of Group II was relative to the increase of their total porosity and their ability to retrain water in their structure. Another important factor might have been the grain size of the minerals, as the fine-grained diabases presented better mechanical characteristics against to the coarse-grained gabbros even if they presented a similar degree of alteration.

Group III was composed of albitites, with limited appearance in the study area, which showed special physico-mechanical properties (Table 2). The low total porosity of aggregates of Group III, in conjunction with their mineralogical features, classified them as the best group of studied rocks. Microscopic observation revealed that these rocks were highly cohesive and least altered; thus, they had low porosity and excellent mechanical behavior. The mineralogical composition combined with the textural characteristics of the aggregate rocks influenced their physical properties, and hence their mechanical properties.

\section{The Impact of the Aggregate Type on the Quality of Concrete}

The physicomechanical properties of the aggregates showed strong correlations with the strength of the concretes (Figure 10). Moisture content and total porosity of the aggregates showed negative correlations with the concrete UCS (Figure 10a,b), and they are related via the following logarithmic equations:

$$
\mathrm{UCS}_{(\mathrm{con})}=-2.189 \ln \left(\mathrm{w}_{(\mathrm{agg}))}+28.931, R^{2}=0.70\right.
$$




$$
\mathrm{UCS}_{(\mathrm{con})}=-1.438 \ln \left(\mathrm{nt}_{(\mathrm{agg}))}+30.27, R^{2}=0.83\right.
$$

This suggests that the high porosity of aggregates negatively affected the bonds between the aggregate and the cement paste. This can be explained by a combination of factors. The increase of the total porosity of the studied aggregate rocks was reliable for the decrease of their mechanical strength. Additionally, variable conditions of hydration reaction likely occurred during the curing of the concrete when rocks with increased porosity were contained, thus resulting in the capricious mechanical behavior of the concrete. Moreover, it was suggested that the large capability of serpentine to adsorb water, apart from reducing its mechanical strength [10], largely disturbed the seamless progress of the hydration reaction, and hence, resulted in weaker concretes.

The UCS and the LA of the studied rocks were directly correlated with the UCS of the relevant concrete specimens (Figure 10c,d). These strong, positive correlations are described by the equations:

$$
\begin{gathered}
\mathrm{UCS}_{(\mathrm{con})}=0.0374 \times \mathrm{UCS}_{(\mathrm{agg})}+27.145, R^{2}=0.73 \\
\mathrm{UCS}_{(\mathrm{con})}=33.055 \mathrm{e}-0.006 \mathrm{LA}_{(\mathrm{agg})}, R^{2}=0.76
\end{gathered}
$$
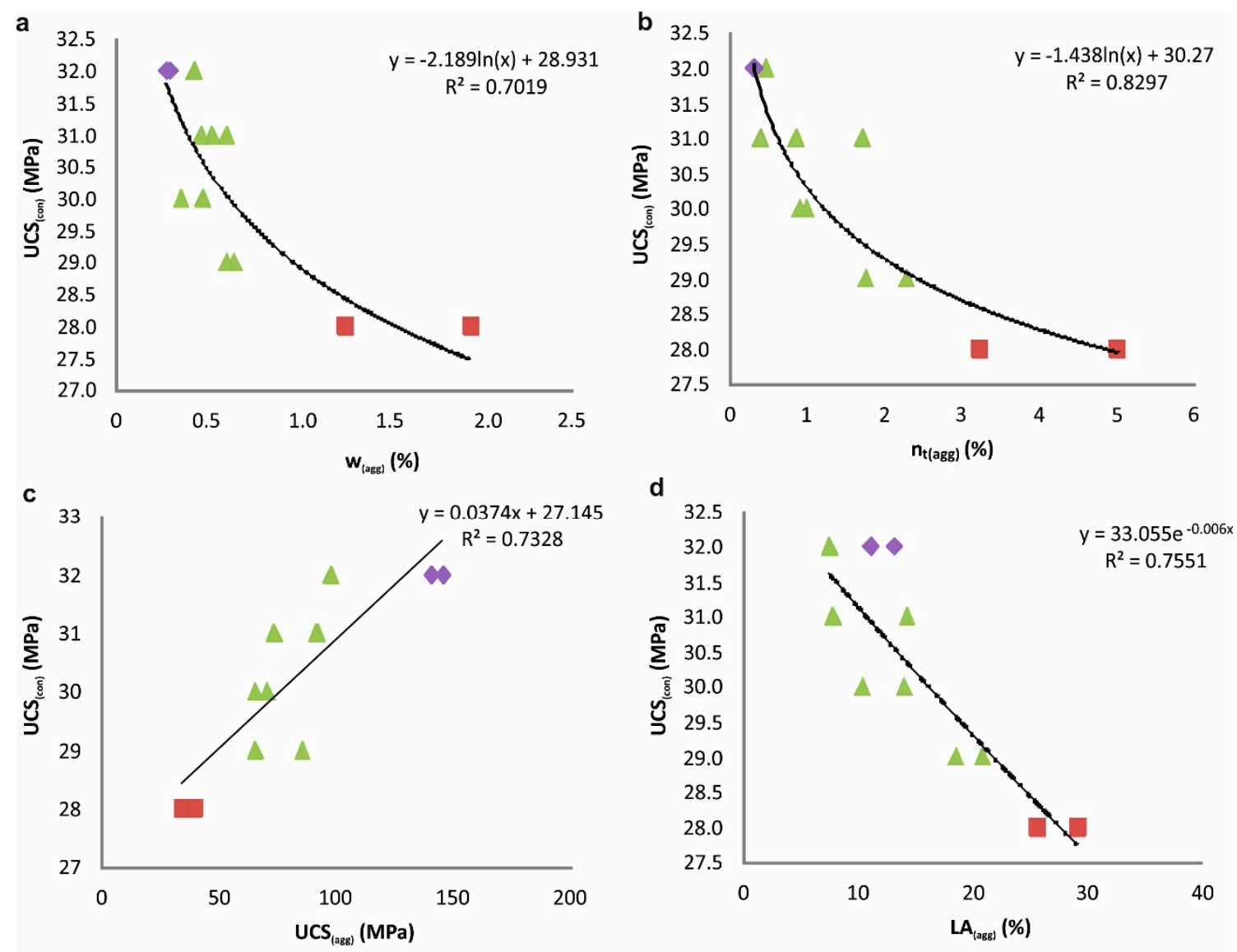

$$
\text { Group I } \Delta \text { Group II } \diamond \text { Group III }
$$

Figure 10. (a) Moisture content $\left(\mathrm{w}_{(\mathrm{agg})}\right)$ of the studied rock samples plotted against the uniaxial compressive strength of concrete $\left(\mathrm{UCS}_{(\mathrm{con})}\right),(\mathbf{b})$ total porosity $\left(\mathrm{n}_{\mathrm{t}(\mathrm{agg})}\right)$ of the studied rock samples plotted against the uniaxial compressive strength of concrete $\left(\mathrm{UCS}_{(\mathrm{con})}\right)$, (c) uniaxial compressive strength $\left(\mathrm{UCS}_{(\mathrm{agg})}\right)$ of the studied rocks plotted against the uniaxial compressive strength of concrete $\left(\mathrm{UCS}_{(\mathrm{con})}\right)$, (d) Los Angeles abrasion value $\left(\mathrm{LA}_{(\mathrm{agg})}\right)$ of the studied rock samples plotted against the uniaxial compressive strength of concrete $\left(\mathrm{UCS}_{(\mathrm{con})}\right)$. 
These relations strongly suggest that the quality of aggregates is a critical factor that determines the quality of the concrete. It is evident from our results that the poor quality serpentinized aggregates yielded concretes with poor strength, whereas the high quality albitite was related to the strongest concrete specimens (Figure 10).

The microroughness of the aggregate particles played another important role in the quality of the concrete products. Group I, with the serpentinized ultramafic samples, exhibited smooth surfaces, which is another determinant negative factor for poor cohesion with the cement paste, and hence, low concrete strength. Furthermore, the low mechanical strength of serpentinite aggregates resulted in its cracking during the uniaxial compressive strength. Microscopic observation of concretes produced with these ultramafic aggregates suggests that fracturing of the cement paste and the aggregate grains of aggregates occurred simultaneously (Figure $6 c, d$ ). This indicates that these aggregates in-service will show poor performance, as cracks that may easily appear in the aggregates due to stress and fatigue will propagate in the cement paste, downgrading its properties. The platy detachments, observed in the serpentine aggregates, and the relatively thick zone of variably increased porosity around them (Figure 7a) comprised defected regions in the concrete, which eventually contributed to the poorer performance.

Generally, the concrete specimens prepared with rocks from Group II and III presented similar UCS values, and both show higher strength relative to the concretes prepared by the aggregates from Group I. According to Onodera et al. [55], the strength of igneous rocks decreases significantly as the mineral grain size increases. The fine-grained diabasic rocks were stronger than the coarse gabbros, and hence, the respective concretes produced with diabasic aggregates showed higher UCS values than the concretes produced by gabbroic aggregates, which is in agreement with the above hypothesis (Table 3). The alteration degree was another crucial factor for the strength of the rocks used as concrete aggregates, as they determined the porosity and the development of weak zones in the rocks. The loss of the material at the interfaces with the cement paste was more intense in the coarse grained gabbroic aggregates, suggesting that the grain size played a negative role in this respect as well. However, the higher strength and the reduced porosity combined with the rougher surfaces of the Group II aggregates relative to those of Group I, were seen as beneficial factors for their quality. The alteration products of rocks of Group II were mainly fibrous actinolite and platy chlorite. These soft minerals juxtaposed with the harder primary clinopyroxene and plagioclase creates high topographic surface features (Figure $5 \mathrm{c}, \mathrm{d}$ ).

The concrete made with Group III aggregates (albitites) showed the best performance, which is in accordance with the high values of produced by intermediate rocks (Group III). Additionally, it presented the highest values of UCS, as well as the low porosity and moisture contents of their aggregates (Table 2). The presence of quartz and albite, which have different crystal habit combined with their minor difference of hardness, created strong topographic microroughness, which determines the effectiveness of the bonding between the aggregate and the cement paste in hardened concrete. The cohesion between the albitite aggregate and the cement paste was particularly good (Figure 6e,f), suggesting that the degree of microroughness had a positive influence on the quality of the concrete.

Inadequate microroughness can adversely affect the mechanical properties of concretes, since the bonds with the cement matrix may not be sufficiently strong to achieve the maximum potential strength of the concrete $[7,21,56]$. However, the observed trace of ASR products around the aggregates in these concretes is a negative factor for their quality. The presence of quartz reacted with sodium and calcium hydroxides from the cement and the albite to form the detrimental gel of the alkali silica reaction (ASR). This is a common negative effect in concretes made with some granitic aggregates, associated with the presence of strained or cryptocrystalline quartz, which is thermodynamically unstable $[57,58]$. However, the topical development of an ASR reaction gels in the studied concretes did not seem to have a significantly detrimental effect on their strength. It is most likely that the propitious effects of their high cohesiveness and strength, discussed above, were not counterbalanced by any negative influence from the localized growth of ASR. 


\section{Conclusions}

The study of different coarse aggregates for the production of concretes leads to the following concluding remarks:

- The collected ultramafic rocks (Group I) were not appropriate for concrete aggregates due to the high degrees of alteration and the presence of serpentine, which significantly decreased the quality of the concretes. The collected mafic aggregate rocks as well as the granodiorite (Group II) were generally considered as suitable for the production of concretes. The intermediate aggregate rocks (Group III) presented overall good physicomechanical properties and resulted in the production of the best quality concretes compared to the other tested lithotypes. The limited presence of alkali-silicate reaction did not influence the final products significantly.

- High porosity and moisture content of the aggregates reduced the quality of the aggregate as well as of the concretes due to disturbance of the hydration reactions. This led to the formation of variably porous and weak zones at the interfaces between the particles and the cement paste.

- Strength and resistance to abrasion and attrition of aggregates was a critical factor that largely determined the quality of the concretes positively. Microroughness was a result of differential hardness of juxtaposed minerals on the surface of the particles and largely affected the bonding between the particles and the cement paste for each lithotype. Smooth serpentine had a negative influence; however, small amounts of soft secondary minerals juxtaposed with hard primary phases had a positive effect on the bonding with the cement paste.

- Petrographic analysis of both of the aggregates and concretes provided pertinent information about the structures concrete material and may help engineers to determine the best construction strategy. The root of concrete deterioration can often be attributed to quality issues seen at the microscopic level of the aggregate materials.

Author Contributions: P.P. participated in the fieldwork, the elaboration of laboratory tests, the interpretation of the results, coordinated the research and wrote the manuscript; P.P.G. participated in the fieldwork, the elaboration of laboratory tests, the interpretation of the results and contributed to the manuscript writing; A.R. participated in the fieldwork, performed the SEM work and the interpretation of the results; P.M.S. participated in the elaboration of laboratory tests and the interpretation of the results; P.L. carried out the XRD analyses and participated in the interpretation of the results; B.T. participated in the fieldwork, the interpretation of the results and contributed to the manuscript writing and K.H. participated in the interpretation of the results.

Funding: This research received no external funding.

Acknowledgments: The authors wish to thank Drakopoulos of the Foundation for Research and TechnologyHellas (FORTH) Institute of Chemical Engineering and High Temperature Chemical Processes (ICE/HT) Rio-Patras, Greece and A.K Seferlis of the Laboratory of Electron Microscopy and Microanalysis, University of Patras for his assistance with the microanalyses and SEM micrographs.

Conflicts of Interest: The authors declare no conflict of interest.

\section{References}

1. Jackson, N. Civil Engineering Materials; Macmillan Press Ltd.: London, UK, 1981.

2. LaLonde, W.S.; Janes, M.F. Concrete Engineering Handbook; Library of Congress: New York, NY, USA, 1961.

3. US Concrete Industry Report; Library of Congress: New York, NY, USA, 2001.

4. Neville, A.M. Properties of Concrete, ELSB 5th ed.; Pearson Education Publishing Ltd.: London, UK, 2005.

5. Taylor, G.D. Materials in Construction, 2nd ed.; Longman Group Ltd., Longman House, Burnt Mill: Harlow, UK, 1994.

6. Rajput, R.K. Engineering Materials, 3rd ed.; S. Chard \& Company Ltd.: New Delhi, India, 2006.

7. Neville, A.M. Properties of Concrete, 4th ed.; Pitman: London, UK, 1995.

8. Aulia, T.B.; Deutschmann, K. Effect of mechanical properties of aggregate on the ductility of high performance concrete. Lacer 1999, 4, 133-147.

9. Thomas, M.D.A.; Folliard, K.J. Concrete aggregates and the durability of concrete. Durab. Concr. Cem. Compos. 2007, 247-281. [CrossRef] 
10. Petrounias, P.; Giannakopoulou, P.P.; Rogkala, A.; Stamatis, P.M.; Tsikouras, B.; Papoulis, D.; Lampropoulou, P.; Hatzipanagiotou, K. The influence of alteration of aggregates on the quality of the concrete: A case study from serpentinites and andesites from central Macedonia (North Greece). Geosciences 2018, 8, 115. [CrossRef]

11. Yilmaz, M.; Turul, A. The effects of different sandstone aggregates on concrete strength. Constr. Build. Mater. 2012, 35, 294-303. [CrossRef]

12. Petrounias, P.; Rogkala, A.; Kalpogiannaki, M.; Tsikouras, B.; Hatzipanagiotou, K. Comparative study of physico-mechanical properties of ultrabasic rocks (Veria-Naousa ophiolite) and andesites from central Macedonia (Greece). Bull. Geol. Soc. Greece 2016, 50, 1989-1998. [CrossRef]

13. Giannakopoulou, P.P.; Tsikouras, B.; Hatzipanagiotou, K. The interdependence of mechanical properties of ultramafic rocks from Gerania ophiolitic complex. Bull. Geol. Soc. Greece 2016, 50, 1829-1837. [CrossRef]

14. Al-Oraimi, S.K.; Taha, R.; Hassan, H.F. The effect of the mineralogy of coarse aggregate on the mechanical properties of high-strength concrete. Constr. Build. Mater. 2006, 20, 499-503. [CrossRef]

15. Rigopoulos, I.; Tsikouras, B.; Pomonis, P.; Hatzipanagiotou, K. The influence of alteration on the engineering properties of dolerites: The example from the Pindos and Vourinos ophiolites (northern Greece). Int. J. Rock Mech. Min. Sci. 2010, 47, 69-80. [CrossRef]

16. Yilmaz, N.G.; Goktan, R.M.; Kibici, Y. Relations between some quantitative petrographic characteristics and mechanical strength properties of granitic building stones. Int. J. Rock Mech. Min. Sci. 2011, 48, 506-513. [CrossRef]

17. Petrounias, P.; Giannakopoulou, P.P.; Rogkala, A.; Lampropoulou, P.; Koutsopoulou, E.; Papoulis, D.; Tsikouras, B.; Hatzipanagiotou, K. The Impact of Secondary Phyllosilicate Minerals on the Engineering Properties of Various Igneous Aggregates from Greece. Minerals 2018, 8, 329. [CrossRef]

18. Shakoor, A.; Bonelli, R.E. Relationship between petrographic characteristics, engineering index properties and mechanical properties of selected sandstones. Bull. Ass. Eng. Geol. 1991, 28, 55-71. [CrossRef]

19. Haney, M.G.; Dhakoor, A. The relationship between tensile and compressive strengths for selected sandstones as influenced by index properties and petrographic characteristics. In Proceedings of the 7th International IAEG Congress, Lisbon, Portugal, 5-9 September 1996; Volume IV, pp. 3013-3021.

20. Turgul, A.; Zarif, I.H. Correlation of mineralogical and textural characteristics with engineering properties of selected granitic rocks from Turkey. Eng. Geol. 1999, 51, 303-317.

21. Smith, M.R.; Collis, L. Aggregates: Sand, Gravel and Crushed Rock Aggregates for Construction Purposes; Spec. Publ. 17; The Geological Society: London, UK, 2001.

22. Miskovsky, K.; Tabora, D.M.; Kou, S.Q.; Lindqvist, P.A. Influence of the mineralogical composition and textural properties on the quality of coarse aggregates. J. Mater. Eng. Perform. 2004, 13, 144-150. [CrossRef]

23. Gonilho Pereira, C.; Castro-Gomes, J.; Pereira de Oliveira, L. Influence of natural coarse aggregate size, mineralogy and water content on the permeability of structural concrete. Constr. Build. Mater. 2009, 23, 602-608. [CrossRef]

24. Kiliç, A.; Atiş, C.D.; Teymen, A.; Karahan, O.; Özcan, F.; Bilim, C.; Özdemir, M. The influence of aggregate type on the strength and abrasion resistance of high strength concrete. Cement Concr. Comp. 2008, 30, 290-296. [CrossRef]

25. Piasta, W.; Góra, J.; Turkiewicz, T. Properties and durability of coarse igneous rock aggregates and concretes. Constr. Build. Mater. 2016, 126, 119-129. [CrossRef]

26. Özturan, T.; Çeçen, C. Effect of coarse aggregate type on mechanical properties of concretes with different strengths. Cem. Concr. 2007, 27, 165-170. [CrossRef]

27. Rogkala, A.; Petrounias, P.; Tsikouras, B.; Hatzipanagiotou, K. New occurrence of pyroxenites in the veria-naousa ophiolite (North Greece): Implications on their origin and petrogenetic evolution. Geosciences 2017, 7, 92. [CrossRef]

28. Mercier, J.; Vergely, P.; Bebien, J. Les ophiolites helleniques 'obductees' au Jurassique superieursont-elles les vestiges d' un ocean tethysienou d' une mermarginale perieuropeenne. C. R. Somm. Soc. Geol. France 1975, 17, 108-112.

29. Saccani, E.; Photiades, A.; Santato, A.; Zeda, O. New evidence for supra-subduction zone ophiolites in the Vardar zone of northern Greece: Implications for the tectonomagmatic evolution of the Vardar oceanic basin. Ofioliti 2008, 33, 65-85.

30. Brunn, J.H. Geological Map of Greece, Veroia Sheet, 1:50.000; IGME: Athens, Greece, 1982. 
31. Decourt, J.; Aubouin, J.; Savoyat, E. Le sillon mesohellenique et la zone pelagonienne. Bull. Soc. Geol. Fr. 1977, 1, 32-70.

32. Michailidis, K.M. Zoned chromites with high MN-contents in the Fe-Ni-Cr-laterite ore deposits from the Edessa area in Northern Greece. Miner. Depos. 1990, 25, 190-197. [CrossRef]

33. Pe-Piper, G.; Piper, D.J.W. The igneous rocks of Greece. The Anatomy of an Orogen. Beitrge zur Regionalen Geologie der Erde (Series). Stuttgart. Gebrder Borntaeger. 2002. [CrossRef]

34. Eleftheriadis, G.; Castorina, F.; Soldatos, T.; Masi, U. Geochemical and Sr-Nd isotopic evidence for the genesis of the Late Cainozoic Almopia volcanic rocks (Central Macedonia, Greece). Min. Petrol. 2003, 78, 21-36. [CrossRef]

35. Mercier, J.L.; Vergely, P. Geological Map of Greece, Edhessa Sheet, 1:50.000; IGME: Athens, Greece, 1984.

36. Part 1: Composition, Specifications and Conformity Criteria for Common Cements; EN 197-1; European Standard: Warsaw, Poland, 2011.

37. AASHTO T255. Standard Method of Test for Total Evaporable Moisture Content of Aggregate by Drying; ASTM International: West Conshohocken, PA, USA, 2000.

38. ISRM Suggested Methods. Rock Characterization Testing and Monitoring; Brown, E., Ed.; Pergamon Press: Oxford, UK, 1981.

39. Resistance to Abrasion of Small-Size Coarse Aggregate by Use of the Los Angeles Machine; ASTM C-131; ASTM: Philadelphia, PA, USA, 1989.

40. Standard Test Method for Unconfined Compressive Strength of Intact Rock Core Specimens; ASTM D 2938-95; American Society for Testing and Materials: West Conshohocken, PA, USA, 2002.

41. Part 3: Procedure and Terminology for Simplified Petrographic Description; EN 932; European Standard: Warsaw, Poland, 1996.

42. Methods for Sampling and Testing of Mineral Aggregates, Sands and Fillers, Part 1: Methods for Determination of Particle Size and Shape; BS 812; British Standard Institution: London, UK, 1975.

43. Standard for Selecting Proportions for Normal, Heavyweight and Mass Concrete; ACI-211.1-91; American Concrete Institute: Farmington Hills, MI, USA, 2002.

44. Part 3: Testing Hardened Concrete. Compressive Strength of Test Specimens; BS EN 12390; British Standard Institution: London, UK, 2009.

45. Standard Practice for Petrographic Examination of Hardened Concrete; ASTM C856; American Society for Testing and Materials: West Conshohocken, PA, USA, 2017.

46. Rigopoulos, I.; Tsikouras, B.; Pomonis, P.; Hatzipanagiotou, K. The impact of petrographic characteristics on the engineering properties of ultrabasic rocks from northern and central Greece. Q. J. Eng. Geol. Hydrogeol. 2012, 45, 423-433. [CrossRef]

47. Hartley, A. A review of the geological factors influencing the mechanical properties of road surface aggregates. Q. J. Eng. Geol. 1974, 7, 69-100. [CrossRef]

48. Barttli, B. The influence of geological factors on the mechanical properties of basic igneous rocks used as road surface aggregates. Eng. Geol. 1992, 33, 31-44. [CrossRef]

49. Rigopoulos, I.; Tsikouras, B.; Pomonis, P.; Hatzipanagiotou, K. Correlations between petrographic and geometrical properties of ophiolitic aggregates from Greece. Bull. Eng. Geol. Environ. 2014, 73, 1-12. [CrossRef]

50. Koukis, G.; Sabatakakis, N.; Spyropoulos, A. Resistance variation of low-quality aggregates. Bull. Eng. Geol. Environ. 2007, 66, 457-466. [CrossRef]

51. Escartin, J.; Hirth, G.; Evans, B. Strength of slightly serpentinized peridotites: Implications for the tectonics of oceanic lithosphere. Geology 2001, 29, 1023-1026. [CrossRef]

52. Frost, B.R.; Beard, J.S. On silica activity and serpentinization. J. Petrol. 2007, 48, 1351-1368. [CrossRef]

53. Diamantis, K.; Gartzos, E.; Migiros, G. Study on uniaxial compressive strength, point load strength index, dynamic and physical properties of serpentinites from Central Greece: Test results and empirical relations. Eng. Geol. 2009, 108, 199-207. [CrossRef]

54. Giannakopoulou, P.P.; Petrounias, P.; Rogkala, A.; Tsikouras, B.; Stamatis, P.M.; Pomonis, P.; Hatzipanagiotou, K. The influence of the mineralogical composition of ultramafic rocks on their engineering performance: A case study from the Veria-Naousa and Gerania ophiolite complexes (Greece). Geosciences 2018, 8, 251. [CrossRef] 
55. Onodera, T.F.; Asoka, K.H.M. Relation between petrographic characteristics, engineering index properties and mechanics properties of selected sandstone. Bull. Ass. Eng. Geol. 1980, 28, 55-71.

56. Kaplan, M.F. Flexural and compressive strength of concrete as affected by the properties of coarse aggregates. J. Am. Concr. Inst. 1959, 55, 1193-1208.

57. Sibbick, R.G.; Page, C.L. Susceptibility of various UK aggregates to alkali-aggregate reaction. In Proceedings of the Ninth International Conference on Alkali-Aggregate Reaction in Concrete, London, UK, 27-31 July 1992; pp. 980-987.

58. Ponce, J.M.; Batic, O.R. Different manifestations of the alkali-silica reaction in concrete according to the reaction kinetics of the reactive aggregate. Cem. Concr. Res. 2006, 1148-1156. [CrossRef]

2018 by the authors. Licensee MDPI, Basel, Switzerland. This article is an open access article distributed under the terms and conditions of the Creative Commons Attribution (CC BY) license (http://creativecommons.org/licenses/by/4.0/). 